KINGA MARULEWSKA Instytut Politologii UMK

\title{
O ISTOCIE MISTRZOSTWA
}

\author{
„Szukam nauczyciela i mistrza \\ Niech przywróci mi wzrok słuch i mowę \\ Niech jeszcze raz nazwie \\ rzeczy i pojęcia \\ Niech oddzieli światło od ciemności” \\ T. Różewicz, Ocalony
}

Dobieranie nauki od wieków nieuchronnie było związane z
mistrzostwem w tym sensie, że aby móc studiować, należało znaleźć mistrza, który by w daną dziedzinę wprowadził. Relacja mistrz - uczeń stała się podstawowa i naturalną formą przy pobieraniu nauki, by wspomnieć choćby Akademię Platońską czy cechy rzemieślnicze. Proces instytucjonalizacji szkolnictwa i umasowienia edukacji dla wielu współczesnych krytyków oznacza jednocześnie zanik relacji mistrz - uczeń oraz uprzedmiotowienie kontaktów pomiędzy studentem oraz profesorem. Jeśli przyjać, że „sens powołania nauczycielskiego polega na tym, by znać pragnienia swoich uczniów i wiedzieć, co może je zaspokoić"1, to nie można tego uczynić bez podejścia podmiotowego, indywidualnego, nastawionego na pojedynczą osobę, a nie anonimowa zbiorowość. Ponieważ jednak współczesny uniwersytet dąży do ujednolicania oraz schematyzacji - programu studiów, wymagań, kontaktów - zasadne wydaje się pytanie, jakie miejsce na uniwersytecie ma mistrzostwo w ogóle, a pytanie o wizję mistrza na uniwersytecie jest poniekąd pytaniem o wizję uniwersytetu jako takiego.

Aby rozważyć naturę mistrzostwa, należy doprecyzować pojęcia zawarte w tytule tej pracy. „Istota” rozumiana jest potocznie jako sedno czegoś i to intuicyjne postrzeganie wydaje się trafne. Filozoficzne rozumienie ,istoty” może być analizowane na trzech zasadniczych płaszczyznach - według koncepcji tożsamościowych,

1 A. Bloom, Umyst zamknięy, Zysk i S-ka, Poznań 1997, s. 19. 
teoriopoznawczych oraz metafizycznych. W kontekście mistrzostwa interesujące są koncepcje metafizyczne, ponieważ rozumienie metafizyczne ,istoty” polega na tym, że „po pierwsze: istota rozumiana jest w kontekście złożeniowej koncepcji bytu, po drugie: rozumienie istoty związane zostało z tym, drieki czemu rzecz byla i jest tym, caym jest". Pojęcie istoty oznacza bowiem „to, czym rzecz jest; coś stałego i koniecznego zmieniającej się rzeczy (...); element konstytutywny w bycie złożonym"’3. Poszukiwanie istoty mistrzostwa, nieuchronnie prowadzi do pytania o to, co stanowi o tym, że kogoś można nazwać mistrzem, natomiast kogoś innego nie. Pomocne może być zanalizowanie funkcjonujących znaczeń słowa „mistrz”, których w języku polskim można wyróżnić aż sześć ${ }^{4}$.

Po pierwsze, pojęcie „mistrz” można rozumieć jako człowieka zdecydowanie lepszego od innych w jakiejś dziedzinie. Jest to dość naturalne rozumienie, wiążące bycie mistrzem z byciem najlepszym. Mistrz w takim ujęciu bliski jest elicie w koncepcji Vilfedo Pareto, według której jest ona określana jako bycie najlepszym w danej dziedzinie. Z byciem najlepszym związane jest również kolejne znaczenie słowa „mistrz” odnoszone do zwycięzców w zawodach sportowych czy konkursach, z punktu widzenia tematyki jednak nieistotne. Mistrz było także pojęciem stosowanym jako tytuł zwierzchników niektórych stowarzyszeń i zakonów rycerskich, jednak również ma ono znaczenie marginalne w niniejszym wywodzie.

"Mistrz" może być także rozumiane jako osoba godna naśladowania, uznana przez innych za wzór. Takie pojmowanie zbliża pojęcie mistrza do pojęcia autorytetu - osoby cieszącej się szczególnym uznaniem. Źródłosłów wywodzący się z łacińskiego auctoritas oznaczającego powagę, znaczenie, wpływ oraz władzę, nakreśla odpowiednie rozumienie mistrza jako autorytetu.

Ostatnie dwa znaczenia pojęcia „mistrz” funkcjonujące w języku polskim związane są z praca - mistrz jest rozumiany jako dyplomowany rzemieślnik, a także wykwalifikowany pracownik nadzorujący pracę podległych sobie robotników. Sa to jednak pojęcia specyficznie odnoszące się do pracy fizycznej, które również w kontekście wybranego zakresu tematycznego można odrzucić.

Kierunek rozważań, jaki wskazują znaczenia pojęcia „mistrz” jako najlepszego w danej dziedzinie oraz autorytetu, wydaje się być

\footnotetext{
2 Powszechna Encyklopedia Filozofii, Polskie Towarzystwo Tomasza z Akwinu, t.5, Lublin 2000 , s. 87.

${ }^{3}$ Tamże, s. 85.

${ }^{4}$ Stownik Jesyka Polskiego, PWN.
} 
najtrafniejszy. Jednak to podwójne rozumienie słowa „mistrz” nie jest kwestią tylko i wyłącznie językowa, gdyż odzwierciedla pewną zasadnicza dla ukazania istoty mistrzostwa kwestię i dotyka najbardziej podstawowego problemu, bez rozwiązania którego do istoty dojść niepodobna. Ten znaczący problem natury filozoficznej sprowadza się do pytania czy mistrz powinien tylko przekazywać swemu uczniowi wiedzę (poziom intelektualny), czy też jego zadaniem jest wychowanie ucznia, a zatem wpojenie mu pewnych zasad moralnych (poziom moralny). Rozróżnienie to jest o tyle znaczące, że wypływa z dwóch odmiennych wizji nauki - pierwsza z nich dąży do maksymalnej obiektywizacji, wyzbycia się wszelkich wartości, które mogłyby zanieczyścić poznanie, druga natomiast zauważa, że poznanie bez wartości jest w ogóle niemożliwe, co więcej - dla człowieka niebezpieczne - a zadaniem mistrza musi być wskazanie odpowiedniej drogi swemu uczniowi tak, aby prócz wiedzy stał się on jeszcze nosicielem starożytnie rozumianej arete, której wykształcenie ma zapobiec użyciu rozumu w służbie nieprawości.

Kwestia ta stanęła wyraźnie przed twórcą nowoczesnego niemieckiego uniwersytetu - Wilhelmem von Humboldtem, gdy w 1808 roku powołany został na stanowisko ministra do spraw wychowania i religii. Rok później, w Berlinie został powołany Uniwersytet im. Fryderyka Wilhelma, a model, jaki reprezentował, ochrzczono mianem uniwersytetu Humboldta. Była to wizja uniwersytetu, która na stałe weszła do myśli społecznej, a jej recepcja nie ograniczyła się do samych Niemiec.

Głosy krytyczne wobec wizji Humboldta, dla których „uniwersytet jako instrumentum dominationis, jako manufaktura urzędnicza, jako fabryka rekrutacyjna - oto (...) jedyny rozsądny sens, jaki można by jeszcze łączyć z tym omszałym urządzeniem", miejsc pobierania wiedzy użytecznej i praktycznej. Taka wizja uniwersytetu jako fabryki „ekspertów-doradców czy menedżerów” ${ }^{6}$ sprowadza jednocześnie naukę na tymże uniwersytecie uprawianą do jej wymiaru ściśle praktycznego (praxis). Można stwierdzić, że kult nauki w takim wypadku zostałby zastapiony „,innym, równie potężnym fetyszyzmem, tj. fetyszyzmem biurokratycznych umiejętności" ${ }^{7}$. Bycie ekspertem w danej dziedzinie wymaga jednak specjalizacji w pewnym wąskim zakresie - ,warunkiem rozwoju nauki stała się specjalizacja ludzi

${ }^{5}$ H. Schnädelbach, Filozofia w Niemczech 1831 - 1933, PWN, Warszawa 1992, s. 45.

${ }^{6}$ A. MacIntyre, Dqiedzictwo cnoty, PWN, Warszawa 1996, s. 171.

${ }^{7}$ Tamże, s. 205. 


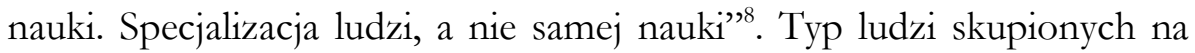
szczegółowym zagadnieniu przy jednoczesnym dyletanctwie w kwestiach pozostałych nazywa Ortega y Gasset „mądro-głupimi” - coraz więcej jest osób znających się na zagadnieniu, które uczynili przedmiotem swych badań, wyspecjalizowanych ludzi nauki, natomiast „mamy też znacznie mniej ludzi kulturalnych i wykształconych"”.

Co takiego postulował Humboldt, żeby uniwersytet zyskał nowestare oblicze? Zasadniczo koncepcja Humboldta przeciwstawiła się zarysowanym wyżej tendencjom. Dwie podstawowe zasady, jakie przyją myśliciel niemiecki to wolność akademicka oraz jedność badań i dydaktyki ${ }^{10}$. Koncepcja nauki i uniwersytetu tegoż filozofa była efektem głębszej refleksji nad edukacją, według niego bowiem ,tylko (...) ta nauka, która pochodzi z wnętrza i może być zaszczepiona we wnętrzu, przekształca również charakter, państwu podobnie jak ludzkości nie może chodzić o wiedzę i mówienie, ale o charakter i działanie" ${ }^{\prime 11}$. Proces edukacji uniwersyteckiej jest rozumiany jako kształcenie przez naukę, rozwój osoby nie tylko intelektualny, ale również moralny i duchowy. Kształcenie się jest „procesem samospełniania się indywiduum, które ucieleśnia sobą prawdziwy moralny świat" ${ }^{12}$. Wyróżniona jako trzeci z etapów edukacji, edukacja uniwersytecka ${ }^{13}$ nie jest przekazem niesymetrycznym, w którym uczeń jest tylko odbiorcą treści, ponieważ sam dąży do wiedzy, sam poszukuje, natomiast wykładowca ma mu w tym zadaniu pomagać. Wzajemność relacji pomiędzy uczniem a mistrzem nie polega na prostym dawaniu i braniu ${ }^{14}$.

Inspiracje myślą Humboldta są żywe również współcześnie. Podobną wizję uniwersytetu można odnaleźć u Allana Blooma, dla którego podstawowym wyzwaniem stojącym przed młodym człowiekiem wstępującym na uniwersytet, jest odpowiedź na pytanie, kim jest on sam - znane gnothi seauton wyryte nad portykiem świątyni w Delfach. Poznanie samego siebie jako element stawania się człowiekiem podkreślone jest

\footnotetext{
${ }^{8}$ J. Ortega y Gasset, Bunt mas, Wyd. Muza, Warszawa 2004, s. 116.

9 Tamże, s. 120.

${ }^{10}$ H. Schnädelbach, dz. cyt., s. 44.

11 Tamże, s. 52.

12 Tamże, s. 53.

13 Pozostałe dwa to natomiast nauczanie podstawowe oraz edukacja szkolna. Nauczanie podstawowe to etap przygotowawczy, natomiast edukacja szkolna ma na celu wprowadzenie do samodzielnej nauki, będącej warunkiem podstawowym studiowania. Por. J. Drewniok, Wilhelma von Humboldta rozważania na temat edukacji $i$ uniwersytetu, „Pressje. Teka pierwsza Klubu Jagiellońskiego”, zima 2002, s. 144.

14 Mistrz-uczeń: wyobrażenia czy rzeczymistość çyli o tworzeniu sžkót naukowych, pod red. Ewy Murynowicz-Hetki, Łódzkie Towarzystwo Naukowe, Łódź 1997, s. 12.
} 
również w encyklice Fides et ratio ${ }^{15}$, a zatem „edukacja liberalna polega właśnie na tym, by pomóc studentom w postawieniu sobie tego pytania, w uświadomieniu sobie, że odpowiedź nie jest ani oczywista, ani jednoznacznie osiagalna” ${ }^{16}$. Kreowanie człowieka w jego człowieczeństwie staje się celem uniwersytetu. Uniwersytety mają być świątynia wiedzy, ponieważ „powstawały $z$ natchnienia nauczaniem $i$ przykładem filozofów” ${ }^{17}$, nie są tylko miejscami „mechanicznego przekazywania wiedzy” ${ }^{18}$, lecz środowiskiem „kształtowania postaw ludzi" "19. Mistrz jest to swego rodzaju kapłan wiedzy ${ }^{20}$, przewodnik po nieznanym świecie - podobny do Wergiliusza oprowadzającego Dantego po piekle i czyśćcu ${ }^{21}$. Jak woła Dante:

„Ty swoim przyjściem i swoimi słowy

Takie w mym sercu wzbudziłeś pragnienie, Żem znowu silny, żem znowu gotowy. (...)

Ty Mistrzem moim, ty Wodzem, ty Panem.

Zmilkłem, on ruszył; na jego skinienie

Poszedłem krajem trudnym i nieznanem." 22

Mistrz nie ma jednak dawać gotowych rozwiązań, jego zadaniem nie jest dawanie odpowiedzi, ma on raczej wspierać rodzenie się wiedzy w uczniu. Dla Sokratesa funkcja nauczyciela była zasadniczo podobna do sztuki położniczej. Metoda maieutyczna ma pomóc wydobyć z ucznia prawdę, do której dojdzie on jednak samodzielnie ${ }^{23}$, co oznacza, że nauczyciel ma być całkiem , jak te akuszerki"24.

Nakreślone powyżej koncepcje relacji pomiędzy uczniem a mistrzem starły się ponownie w myśli niemieckiej kilkadziesiąt lat po

15 Jan Paweł II, Fides et ratio, http://www.opoka.org.pl/biblioteka/W/WP/jan_pawel_ii/encykliki/fides_ratio_0.ht $\mathrm{ml}, 07.12 .2006$.

16 A. Bloom, dz. cyt., s. 21.

17 Tamże, s. 323.

18 K. Szczerski, Uniwersytet a powinności moralne, „Pressje. Teka pierwsza Klubu Jagiellońskiego", zima 2002, s. 53.

19 Tamże.

${ }^{20}$ E. Marynowicz-Hetka, dz. cyt. s. 13.

21 Pierwszą rozmowę między Dantem a Wergliuszem można odnaleźć w cz. 1 - Piekło, pieśń 1.

22 Dante, Boska komedia, cz. 1 - Piekło, pieśń 3, wersy 136-142; dostępna: http:/ /www.boskakomedia.korona-pl.com/porebowicz/a02.html, 7.12.2006.

${ }^{23}$ W. Tatarkiewicz, Historia filozofii, PWN, t. 1, Warszawa 2003, s. 76-78.

24 Platon, Teajtet, 150 c-d, Kęty 2002; Cyt. za: P. Patucha, Sokratejska filozofia wychowania, http://www.racjonalista.pl/kk.php/s,3740, 07.12.2006. 
reformach humboldtańskich. Ich wyrazicielami było dwóch żyjących równolegle myślicieli schyłku XIX i początku XX wieku - mowa tutaj o Maxie Weberze oraz Fryderyku Nietzschem.

Wizja mistrzostwa oraz zadań filozofa czy naukowca różnia zasadniczo tych myślicieli - w nich odrodziła się na nowo dyskusja na temat roli mistrza zwłaszcza w kontekście uniwersytetu oraz nauki na tym uniwersytecie uprawianej. Nietzschego można określić jako zwolennika koncepcji odpowiedzialnego wychowania uczniów przez mistrza, wykraczającego poza samą czystą wiedzę rozumianą jako zbiór faktów, natomiast Weber, uważany za uczonego, który przełamał tradycje pozytywistyczne w socjologii, postuluje obiektywność i uwolnienie od wartości. Te różnice można wyjaśnić po części ze względu na dziedzinę, w jakiej poruszaja się obydwaj myśliciele. Nietzsche był filologiem klasycznym i filozofem, nie zajmował się empiria, z jaka obcował Weber, który rozpoczął swoja karierę od historii, natomiast później stał się klasykiem nauk społecznych, zwłaszcza socjologii. Nietzsche swoje wywody prowadził z punktu widzenia myśli filozoficznej, Weber natomiast pragną nadania nowego znaczenia naukom społecznym poprzez określenie specyficznych metod badawczych, co z kolei pozwoliłoby przezwyciężyć poczucie upośledzenia w stosunku do nauk przyrodniczych.

Weberowski postulat wolności od wartości (Wertfreiheit) bierze się z pozytywistycznego ${ }^{25}$ dążenia do stworzenia nauki obiektywnej, pozbawionej skaz takich, jak podejście normatywne. Fakty - oto czego szuka Weber. Wizja świata jako chaosu, popularna w ówczesnej myśli niemieckiej, nie doprowadziła Webera do relatywizmu - sądził on, że na morzu światopoglądów istnieje wyspa, po której można przejść suchą stopa, a tą wyspa jest nauka, ponieważ ,jest i pozostanie prawda, że poprawne metodologicznie naukowe dowodzenie w dziedzinie nauk społecznych, jeżeli chce osiagnać swój cel, musi zostać uznane za prawidłowe nawet przez Chińczyka, albo też (...) musi do tego celu (...) przynajmniej dążyć" ${ }^{26}$. Nawiązując do Rickerta odróżniał on sądy wartościujące (Werturteil) oraz odniesienia do wartości (Wertbeqiehung). Pierwsze $z$ nich są w nauce absolutnie zakazane, natomiast bez odniesień do wartości nauka jest niemożliwa, tyle, że „nauki społeczne zajmują się ludzkimi sądami wartościującymi, ale same ich nie wydają, pozostając

$25 \mathrm{~J}$. Szacki mówi nawet o „powrocie do pozytywizmu” u Webera polegajacym na odrzuceniu rozróżnienia na nauki społeczne i przyrodnicze. Por. J. Szacki, Historia myśli socjologicznej, PWN, Warszawa 2005, s. 459.

${ }^{26}$ M. Weber, Obiektywność poznania w naukach spotecznych, w: A. Chmielecki, Problemy socjologii wiedsy, PWN, Warszawa 1985, s. 77. 
wolne od wszelkiej stronniczości" ${ }^{27}$. Jedynym wyjątkiem od tej zasady neutralności jest wybór tematu - w tym przypadku uczony zachowuje się jak każdy zwyczajny człowiek.

Obiektywność jest rozumiana u Webera dwojako - w pierwszym znaczeniu jest to cecha wiedzy jako takiej - „wiedza obiektywna”, natomiast w drugim jest to cecha samego badacza. Rozwijając to drugie rozumienie można za Stanisławem Andreskim stwierdzić, że jest to wola nieulegania oddziaływaniu uczuć i pragnień podczas rozumowania połaczona $\mathrm{z}$ gotowością do pogodzenia się $\mathrm{z}$,niewygodnymi wnioskami”, ale również chęć do konfrontacji swych poglądów z rzeczywistością empiryczną i poddanie ich ocenie pod względem spójności logiczneje ${ }^{28}$.

Paradygmat Wertfreiheit, nazywany paradygmatem niewartościowania, należy uważać za zasadę metodologiczną, zgodnie z którą za naukowe uznaje się twierdzenia etycznie neutralne, wolne od zaleceń praktycznych. Zarysowane zatem zostaje kryterium demarkacji nauki - naukowe oznacza neutralne etycznie. Czym innym jednak jest neutralność semantyczna a czym innym praktyczna, gdyż „nikt nie będzie traktowany jako neutralny, jeżeli będzie odkrywał to, co inni chcieliby przemilczeć"29.

Wizja nauki i naukowca - mistrza oraz jego relacji z uczniami najpełniej została wyrażona w Wissenschaft als Beruf - wykładzie wygłoszonym w Monachium 7 listopada 1917 roku, trzy lata przed śmiercią myśliciela, a wydanym w 1919 roku. Kształcenie naukowe na uniwersytecie jest dla Maxa Webera „zajęciem duchowoarytokratycznym" 30 niedostępnym każdemu, nacechowanym pewną lotnością i wzniosłością. Aby zajmować się nauką trzeba posiadać wewnętrzne powołanie, ponieważ tylko „czynność, którą można wykonać z pasją, jest dla człowieka jako człowieka cokolwiek warta" ${ }^{31}$. Graniczy ona ze sztuka, potrzebuje natchnienia, a nie jest - jak sądziło wielu młodych współczesnych myślicielowi - „zadaniem rachunkowym, czymś, co niczym w jakiejś fabryce, produkowane jest przez zimny intelekt w laboratoriach"32. Z drugiej jednak strony nauka zmienia się w

${ }^{27}$ J. Szacki, dz. cyt., s. 464.

${ }^{28}$ S. Andreski, Maxa Webera olsnienia i pomytki, PWN, Warszawa 1992, s. 45.

29 Tamże, s. 38.

${ }^{30}$ M. Weber, Nauka jako zawód i powołanie, w: tenże, Polityka jako zawód i powotanie, Znak, Kraków 1998, s. 116.

31 Tamże, s. 117.

32 Tamże, s. 118. 
zawód, a uczony coraz częściej przypomina eksperta-fachowca, o którym pisał również MacIntyre ${ }^{33}$.

Jaką zatem wizję mistrza w kontekście tak postrzeganej nauki można dostrzec u Webera? Wydaje się, że w jego tekstach można wyróżnić trzy zasadnicze cechy mistrza na uniwersytecie. Po pierwsze, osoba zajmująca się nauka powinna posiadać zarówno kwalifikacje uczonego jak i wykładowcy ${ }^{34}$, co jest zbieżne z postulatem Humboldta dotyczącym jedności badań i dydaktyki. Nie wszyscy jednak dysponują takim talentem, żeby posiadać zarówno ogromne możliwości intelektualne i dydaktyczne, i nie są to wyjątki. Co więcej, często miarą bycia dobrym wykładowca jest dla władz uczelnianych ilość studentów na wykładzie, co jednak może prowadzić do błędnych wniosków choćby ze względu na wpływ tematyki badawczej czy sposobu przemawiania. Z naturą badacza związana jest kwestia dążenia do odkrycia czegoś nowego - nie da się dokonać niczego ważnego i interesującego bez specjalizacji w ramach danej dziedziny, co prowadzi również do rezygnacji $\mathrm{z}$ całościowego objęcia wiedzy. Mistrz-dydaktyk powinien wykładać problemy naukowe tak, aby stały się dostępne dla jeszcze niewykształconych, chociaż skłonnych do poznania młodych umysłów ${ }^{35}$. Łatwo może on zrazić do siebie uczniów, jeśli zamiast wprowadzić ich w zagadnienie stopniowo, będzie wymagał od razu wypłynięcia na szerokie wody.

Druga cechą mistrza, jest jego neutralność (Wertfreiheit) na sali wykładowej, to znaczy wtedy, kiedy występuje on w roli naukowca. Temat ten pojawia się kilkakrotnie w pracy Webera i za każdym razem jest mocno podkreślany. Jedna z przyczyn jest to, że nauka nie daje odpowiedzi na jedyne ważne dla człowieka pytania - co powinniśmy czynić? Jak powinniśmy żyć? Daje natomiast wiedzę, aby opanować życie w sposób techniczny ${ }^{36}$. Pojawia się tutaj pytanie, czy wykładowca powinien analizować np. bieżąca politykę. Weber odpowiada stanowczo, że nie, ponieważ to należy do proroka lub demagoga. Słowa mistrza maja być „lemieszami spulchniającymi grunt kontemplacyjnego myślenia”,37, a nie orężem w jakiejś walce - zachwianie tego porządku uważa niemiecki myśliciel za karygodne. Dobry wykładowca czyni tak dlatego, że chce nakłonić słuchacza, aby sam mógł zająć stanowisko w stosunku do omawianych problemów zgodnie ze swoimi wartościami, jest to kwestia

\footnotetext{
33 Por. A. MacIntyre, dz. cyt. s. 171.

${ }^{34}$ M. Weber, Nauka jako zawód i powołanie, dz. cyt., s. 115.

35 Tamże, s. 116.

36 Tamże, s. 127.

${ }^{37}$ Tamże, s. 128.
} 
intelektualnej uczciwości wobec uczniów. Oceny należą natomiast do autorytetów z innych dziedzin np. religii.

Jako trzecią cechę można wyróżnić te elementy pozytywne (w odróżnieniu od negatywnych polegających na powstrzymaniu się mistrza od pewnych działań), które mistrz ma wpoić swoim uczniom. Przede wszystkim zaliczyć do nich można uznawanie faktów dla siebie niewygodnych ${ }^{38}$. Jest to „osiagnięcie moralne”, jeśli uczniowie będą się do tego postulatu stosować. Wykładowca ma również wyposażyć swoich podopiecznych w wiedzę techniczna, metody myślenia i rozumowania oraz jasność rozumianą jako świadomość doboru odpowiednich środków do danego celu - wszystko to stanowi warsztat ucznia, który dalej powinien radzić sobie samodzielnie.

Wizję relacji pomiędzy mistrzem a uczniem wyłaniającą się z myśli Maxa Webera można poddać krytyce w kilku punktach. Jest ona produkcją „fabryczną” uczniów wyposażonych w prawdzie w niezbędne przygotowanie metodologiczne, natomiast pominięcie kwestii tego, co jest Prawdą czy Dobrem rodzi niebezpieczeństwo, że wiedza przez nich zdobyta będzie wykorzystywana do celów pragmatycznych, choć nie dobrych $^{39}$. Zasada neutralności sali wykładowej wobec nieprawdy czy też zła może stać się przyczyną wykształcenia uczniów, dla których wszystkie poglądy są jednakowo słuszne i dopuszczalne. Co więcej, niemożliwe jest uwolnienie się od wartościowania - sam wybór tematu jest już wyborem normatywnym, z czym z resztą Weber się zgadzał. Warto również podkreślić, że czas spędzony na uniwersytecie jest okresem zdobywania wiedzy, a nie bycia wychowywanym. Mistrz jest skarbnica wiedzy, ale niczym ponadto.

Zupełnie odmienną koncepcję wysunął Fryderyk Nietzsche w swoim wczesnym okresie zwanym romantycznym, kiedy to pozostawal pod wpływem pism Schopenhauera. W latach 1873-1876 powstawał cykl esejów m.in. dotyczący roli mistrza w rozwoju duchowym młodego człowieka. Mistrz-przewodnik potrzebny jest w kształceniu akademickim, ponieważ „od młodzieży trudno wymagać, ażeby od razu umiała odróżnić frazes od prawdy, pusty krzyk od odwagi”40. Jednak, co ciekawe, sam Nietzsche swojego mistrza porzucił $i$ udał się na

\footnotetext{
38 Tamże, s. 130.

${ }^{39} \mathrm{Tu}$ można choćby przywołać za A. Zybertowiczem kwestię produkcji mydła z ludzi, która z punktu widzenia technologicznego i pragmatycznego jest możliwa do zrealizowania i korzystna, natomiast moralnie niedopuszczalna.

${ }^{40}$ M. Bobrzyński, O konieczności zaangażowania publicznego, „Pressje. Teka pierwsza Klubu Jagiellońskiego”, zima 2002, s. 194.
} 
samodzielną wędrówkę filozoficzną, tworząc jedną z najbardziej znanych współcześnie koncepcji filozoficznych.

Ludzie nauki według Nietzschego nie reprezentują sobą takich zalet, jak to miało miejsce kiedyś. Wykształcenie stało się metoda zdobywania pieniędzy, środkiem do pewnego celu, a nie celem samym w sobie. System edukacji stara się wykształcić możliwie dużo ludzi mających odpowiednie kwalifikacje, wspomaga jednostkę w jej dążeniu do zysku. „Stany uczone nie sa już latarniami, wskazującymi drogę" ", ale odpowiednie wychowanie może przeciwstawić się temu stanowi rzeczy. Uczeń woła do mistrza o odpowiednie pokierowanie mówiąc „widzę nad sobą coś wyższego i bardziej ludzkiego niż ja sam, pomóżcie mi wszyscy to osiągnaćc" ${ }^{42}$ - drogą do tego staje się przylgnięcie do jakiegoś wielkiego człowieka, geniusza, który może wskazać odpowiednią drogę. Przebywanie w towarzystwie takich osób jest ogromną radością, ponieważ „najgłębiej sięgaja myśla, a przeto musza kochać to, co najbardziej żywe i jako mędrcy ostatecznie skłaniać się ku pięknu" 43 . Relacje mistrz - uczeń moga stać się recepta na upadek w nauce i kulturze.

Dwie podstawowe zasady wychowania to rozpoznać mocne strony wychowanka, aby temu talentowi nadać postać dojrzałą, natomiast pozostałe zadatki rozwijać w miarę możliwości. Może to doprowadzić do pielęgnowania talentu, którego uczeń nie znosi, a zatem prawdziwy wychowawca „odkrywałby owa siłę centralna, ale umiałby też zapobiec, by nie zniszczyła innych sił: zadaniem jego (...) byłoby przekształcić całego człowieka w ożywiony system słoneczny i planetarny oraz rozpoznać prawa jego wyższej mechaniki" ${ }^{44}$. Wychowanie moralne jest integralną częścią wychowania w ogóle, jednak we współczesnych myślicielowi czasach cnota była postrzegana jako „słowo staroświeckie, wywołujące uśmieszek" ${ }^{45}$, a wychowanie moralne zeszło na margines. Niemożliwe jest jednak wykształcenie uczonego bez tego niezbędnego elementu - sama wiedza czy umiejętności nie są warunkiem wystarczającym. Mistrz powinien jednak nie tylko kształtować odpowiednie postawy u swego podopiecznego, ale również całym swoim postępowaniem dawać świadectwo zasadom, o których mówi lub pisze. Nietzsche jest tu w swoich poglądach zbliżony do filozofów starożytnej Grecji czy Rzymu, którzy świadczyli o przyjętej filozofii całym swoim

\footnotetext{
${ }^{41}$ F. Nietzsche, Niewcz̧esne rozważania, Znak, Kraków 2006, s. 197.

42 Tamże, s. 215.

43 Tamże, s. 180.

44 Tamże, s. 174.

45 Tamże, s. 176.
} 
życiem - by wspomnieć choćby Sokratesa czy Diogenesa z Synopy ${ }^{46}$ mieszkającego w beczce.

$\mathrm{Na}$ mistrza czekaja jednak pewne niebezpieczeństwa związane $\mathrm{z}$ biurokratyzacją i instytucjonalizacją kształcenia. Otóż może zdarzyć się tak, że w godzinach wyznaczonego wykładu nie będzie on miał żadnych głębszych przemyśleń na dany temat. Pracując na uczelni zobowiązał się jednakże do wypełniania tego obowiązku i choć nie ma nic ciekawego i twórczego do powiedzenia, to stawić się na swój wykład musi. Zabiera mu to wolność rozmyślania, „podążania za swoim geniuszem wtedy, kiedy ten go wzywa" ${ }^{47}$.

Uczony, zajęty rozwiązywaniem łamigłówek nauki normalnej ${ }^{48}$, żywi niechęć do kogoś z polotem, geniusza, który go przewyższa. Żeby jednak taki geniusz mógł powstać niezbędne jest kilka cech charakteru, które należy wykształcić - po pierwsze musi on posiadać „niezależny męski charakter" ${ }^{\prime 9}$ i znajomość ludzi, z drugiej strony należy go odciąć od uczonej edukacji, patriotycznych ograniczeń czy przymusu zarabiania po to, aby mógł naprawdę wolny i nieskrępowany rozwijać swoje talenty. Przeciwieństwem takiego geniusza jest uczeń, który upycha do głowy „najśmielsze i najwymyślniejsze koncepty ludzkiego ducha"50 po to, aby zdać egzamin z danego przedmiotu. Takie coś to dla Nietzschego galimatias, kpina $z$ prawdziwej nauki i wychowania, dżungla, wychowanie do egzaminu, a nie do myślenia ${ }^{51}$.

Nietzsche podejmuje również kwestię stosunku państwa do edukacji uniwersyteckiej. Zauważa on, że państwu nie zależy na prawdzie, lecz na prawdzie jemu użytecznej, stosowalnej tu i teraz, prawdzie dostosowanej do aktualnych potrzeb. Nic dziwnego więc, że przestrzega przed standardową edukacją, będącą przecież narzędziem w rękach władzy, stawiając na osobiste relacje pomiędzy mistrzem a jego uczniem. Mistrz powinien również wykształcić w podopiecznym umiejętność odpowiedniego traktowania państwa: ograniczenia codziennej lektury gazet czy służenia jakiejś partii, ponieważ, kto posiada w sobie furor philosophicus nie znajdzie już miejsca - co więcej, nie powinien nawet - na furor politicus ${ }^{52}$.

\footnotetext{
46 W. Tatarkiewicz, dz. cyt., s. 80.

${ }^{47}$ F. Nietzsche, dz. cyt., s. 243.

48 Por. T. S. Kuhn, Struktura rewolucji naukowych, Aletheia, Warszawa 2001.

${ }^{49}$ F. Nietzsche, dz. cyt., s. 239.

50 Tamże, s. 245.

51 Tamże.

52 Tamże, s. 237.
} 
Pozostaje jeszcze nakreślić wizję wskazywania wartości przez mistrza. Jest to w tej koncepcji coś zupełnie naturalnego, ponieważ „obcowanie z nauka, nie kierujące się i nie ograniczone jakąśs wyższą maksyma pedagogiczną, a rozbuchane (...) jest (...) równie szkodliwe jak ekonomiczna zasada laissez faire dla moralności całych narodów" ${ }^{\text {". Pisząc }}$ o Schopenhauerze, Nietzsche nakreśla uczucia, jakie wywołuje w nim obcowanie z mistrzem: dobroć, zaufanie, szczerość, naturalność oraz uczciwość, pogoda ducha oraz stałość poglądów. Prawdziwy mistrz swoja postawą prowadzi ucznia w stronę „czystej nauki” ${ }^{54}$, ponieważ pokazuje mu, co jest naprawdę wartościowe i godne uwagi.

Taka postawa budzi jednak niebezpieczeństwo dla ucznia i pokusę dla mistrza, aby - jeśli to mistrz „fałszywy”, a zatem taki, który nie dba o prawdziwy rozwój swego podopiecznego albo nieznający się na rzeczy - frazesy prezentować tak, jakby były prawda. Na nic wtedy cały proces wychowania. Dlatego też tak ważne jest znaleźć odpowiedniego mistrza, co może zająć wiele czasu. Jednak warto, ponieważ może on nas doprowadzić tam, gdzie nigdy sami byśmy nie doszli.

Rozwiązanie problemu istoty mistrzostwa możliwe jest tylko wtedy, gdy przyjąć, że dwie zaprezentowane koncepcje to typy idealne znajdujące się na horyzontalnej skali od całkowitej neutralności do normatywności. Rozwiązaniem jest arystotelesowski złoty środek popadnięcie w skrajności w obie strony może zakończyć się wychowaniem nie takim, jakie założyliśmy. Z jednej strony obiektywna prezentacja świata może pomóc w samodzielnym podjęciu decyzji przez ucznia, z drugiej jednak przesadna obiektywizacja sprowadzona do czystych faktów zaburza specyficzną relację pomiędzy mistrzem a uczniem, którą intuicyjnie za Grekami można pojmować jako coś pomiędzy podziwem a przyjaźnią. „Czysta”, pozytywistyczna wiedza jest wiedzą beznamiętna, natomiast więź pomiędzy mistrzem a uczniem z pewnością związana jest $z$ pewnymi uczuciami. Co więcej, wartościowanie i tak ,przemycane” jest w nauce ${ }^{55}$ - niemożliwe jest uwolnienie się od niego, co zauważał nawet Weber. Zatem realizacja czystej formy mistrzostwa neutralnego jest z zasady niemożliwa. Natomiast odchylenie w druga stronę - przekazywania zasad mistrza uczniowi, zwłaszcza przy bezkrytycznej postawie tego ostatniego, jest tylko kopiowaniem mistrza, niczym więcej, bez gwarancji jednak, że

\footnotetext{
53 Tamże, s. 175.

54 Tamże, s. 183.

55 L. Strauss, Caym jest filozofia polityki?, w: Wspótczesna filozofia polityki. Wybór tekstón źródłowych, pod red. Doroty Pietrzyk-Reeves'a, Bogdana Szlachty, Wyd. Dante, Kraków 2003, s. 63-75.
} 
kopia również stanie się mistrzem. Rodzi to również niebezpieczeństwa, o których wspomniano powyżej.

Jeżeli przyjąć, że zadaniem uniwersytetu jest „stawiać w centrum uwagi wieczne pytania" ${ }^{56}$, to wskazuje nam to również na główne zadania mistrza. Można zatem powiedzieć, że „uniwersytet nie zna odpowiedzi, lecz wie, co to jest otwartość i jakie są pytania"57. Sokratejska metoda dochodzenia do prawdy wydobywanej z samego ucznia wydaje się być ideałem, który rozwiązywałby wszelkie wattpliwości - zakłada ona jednak, że taka prawda w człowieku istnieje, należy ją tylko odkryć.

Powyższe rozważania można odnieść do sytuacji współczesnej. W obecnym systemie ,zatłuczona została indywidualność profesora i indywidualność studenta"58. Uniwersytet stał się miejscem zdobywania wiedzy, a nie namysłu nad tą wiedza, a poszukiwanie odpowiedzi na zasadnicze pytania, co niegdyś było podstawą wykształcenia jako takiego, zostało zmarginalizowane na rzecz zdobywania wiedzy praktycznej, przydatnej w późniejszym życiu zawodowym, nakierowanej na sukces i mierzalny zysk. Pojawia się tendencja do szybkiej specjalizacji kierunkowej - już od pierwszego roku, kosztem wykształcenia ogólnego. Mistrzowie nie są potrzebni, stanowią tylko element systemu pomiędzy egzaminem wstępnym na studia a otrzymaniem upragnionego dyplomu magisterskiego. Bezpośrednia relacja często zostaje zastapiona biurokracja, a coraz większe znaczenie uzyskuje obecnie administracja uniwersytecka. $\mathrm{Na}$ jednym roku wielu kierunków jest stu czy nawet kilkuset studentów - osoba zostaje wtedy sprowadzona do numeru indeksu w protokole z egzaminu. Kiedy brak jest egzaminu ustnego jedynej możliwości spotkania twarzą w twarz, student tym numerem pozostaje.

Jednak nadal - mimo przeszkód - wokół mistrzów skupiają się żądni wiedzy uczniowie. Możliwe jest to dzięki powtórnemu przeniesieniu kontaktów w ramy niekoniecznie wytyczone przez sama instytucję uniwersytetu ${ }^{59}$. Powrót do tradycyjnego pojmowania relacji mistrz - uczeń jest coraz trudniejszy, jednak nadal możliwy.

\footnotetext{
56 A. Bloom, dz. cyt., s. 300.

57 Tamże, s. 301.

${ }^{58}$ E. Marynowicz-Hetka, dz. cyt., s. 27.

59 Doskonałym przykładem moga być choćby relacje pomiędzy Henrykiem Elzenbergiem oraz Zbigniewem Herbertem, czego wyrazem są listy opublikowane przez Wydawnictwo Literackie (Z. Herbert, H. Elzenberg, Korespondencja, „Zeszyty Literackie", 2002).
} 